\title{
Modification of Prolactin Receptor (PRL-R) Expression by PRL in the Mouse Liver: Estimation of the Ratio of Two Forms of PRL-R mRNAs by "One-Sided Competitive PCR"
}

\author{
Manabu Matsuda and Takao Mori \\ Department of Biological Sciences, Graduate School of Science, \\ University of Tokyo, Bunkyo-ku, Tokyo 113, Japan
}

\begin{abstract}
We developed new means of measuring the ratio of the short to the long form ( $S / L$ ratio) of the mouse prolactin receptor ( $\mathrm{mPRL}-\mathrm{R}$ ) CDNA by PCR using a primer common to the two forms and two specific primers. A means of estimating the amount of MPRL-R cDNA by competitive PCR was also established. We confirmed that these procedures were valid, since the $S / L$ ratio of standard DNA was unaltered by one-sided CPCR amplification under the following conditions: the ratio was between 0.1 and 4 , and the amount of CDNA was between $10^{3}$ and $10^{7}$ molecules/tube.

The result of one-sided CPCR showed that the short form was dominant in the mouse liver, while the long form was dominant in other tissues. In addition, pituitary grafting increased the $S / L$ ratio in the liver, implying that prolactin down-regulated the functional long form of PRL-R and lowered tissue sensitivity to prolactin itself by modifying the post-transcriptional regulation of PRL-R.
\end{abstract}

\section{INTRODUCTION}

Since Boutin et al. (1988) first reported the primary structure of rat prolactin receptor (PRL-R) mRNA, the human (Boutin et al., 1989), rabbit (Edery et al., 1989), mouse (Davis and Linzer, 1989; Moore and Oka, 1993), rat (Shirota et al., 1990), cattle (Scott et al., 1992), chick (Tanaka et al., 1992), pigeon (Chen and Horseman, 1994), and tilapia (Sandra et al., 1995) PRL-R has been cloned. In rats and mice, there are at least two receptor isoforms (short and long) of which the cytoplasmic domains differ as the result of alternative splicing of a single gene (Kelly et al., 1992). One long and three short forms of PRL-R mRNAs have been identified in several mouse organs, and they may correspond to high and low molecular weight PRL-R, respectively (Haldosen and Gustafsson, 1990). Although there are no differences in the binding activity between the long and short forms, only the long form functions in signaling to the milk protein gene in mammary gland cells (Lesueur et al., 1991) or to interferon regulatory factor-1 in Nb2 T-lymphoma cells (O'Neal and Yu-Lee, 1994). Hence, the fact that PRL up-regulates the PRL binding activity of cells (Posner et al., 1975; Amit et al., 1985; Savoie et al., 1985; Barash et al., 1988) does not mean that PRL up-regulates the functional response of cells to the ligand. Tissue sensitivity to PRL may be regulated by modifying the composition of PRL$R$ molecules in post-transcriptional regulation, probably at the splicing step. In fact, the expression of multiple forms of mouse
PRL-R (mPRL-R) mRNA is differentially regulated depending on the physiological or hormonal situation ( $\mathrm{Hu}$ and Dufau, 1991; Buch et al., 1992; Clarke and Linzer, 1993). Here, we investigated whether or not PRL regulates tissue sensitivity to PRL itself by modifying the composition of PRL-R.

A combination of reverse transcription (RT) followed by the polymerase chain reaction (PCR) is useful for analyzing low levels of mRNAs (Chelly et al., 1988), but it sometimes does not yield quantitative information especially when the amount of the target mRNA is very small. Becker-Andre and Hahlbrock (1989) and Gilliand et al. (1990) have described competitive PCR (CPCR) in which DNA fragments containing the same primer template sequences as the target compete for primer binding and amplification (Siebert and Larrick, 1992). Competitive PCR allows low levels of mRNAs to be quantified and has been applied to studying the differential expression of gene isoforms such as the glucose transporter, GLUT1 and GLUT4 (Sivitz and Lee, 1991). Here we developed a means of examining the ratio of the short to the long form of $\mathrm{mPRL}-\mathrm{R}$ ( $S / L$ ratio) cDNAs, by means of "one-sided CPCR". The procedure consisted of PCR using a primer common to both forms and primers specific to each of them. We then studied the effect of hyperprolactinemia induced by pituitary grafting on the $S / L$ ratio. In addition, a means of measuring the level of CDNA encoding the extracellular domain of PRL-R was developed using CPCR, to estimate amount of PRL-R CDNA in cDNA samples. 


\section{MATERIALS AND METHODS}

Animals

BALB/c mice were purchased from CLEA Japan, Inc. (Tokyo, Japan) and housed in plastic cages with wood shavings under controlled temperature $\left(25 \pm 0.5^{\circ} \mathrm{C}\right)$ and lighting (12 hr from 6:00 to 18:00). They were given a commercial diet (CE-7; CLEA Japan) and tap water ad libitum. All procedures used on the mice were described in detail in a protocol that was approved by the Animal Care and Use Committee of the Graduate School of Science, University of Tokyo, and all experiments conformed to the regulations described in the $\mathrm{NIH}$ Guide to the Care and Use of Laboratory Animals.

The mice were killed at 2 months of age without further treatment. In addition, hyperprolactinemic mice were prepared as described (Matsuda et al., 1995). Two-month-old female mice were transplanted with a single anterior pituitary gland obtained from male litter-mates under the left kidney capsule (PG mice), or were sham-operated as the control group. These mice were sacrificed at 15 days after the operation, when the circulating level of prolactin increased to more than 10-fold the control value (Matsuda et al., 1994).

\section{Preparation of cDNA samples}

Tissues were dissected from decapitated mice and stored in liquid nitrogen until use. Total RNA was isolated from the frozen tissues using acid guanidinium-phenol-chloroform method (Chomczynski and Sacchi, 1987). The concentration of total RNA was estimated by the absorbance at $260 \mathrm{~nm}(1 \mathrm{OD}$ unit was estimated at $40 \mu \mathrm{g} / \mathrm{ml})$ using a spectrophotometer (Ubest-30; Japan Spectroscopic Co., Ltd., Tokyo). After denaturation at $90^{\circ} \mathrm{C}$ for $5 \mathrm{~min}$, the RNA samples were ice-chilled, then template cDNAs for PCR were generated from the samples by RT according to standard procedures. RT of $2 \mu \mathrm{g}$ total RNA was performed in a $20-\mu$ l reaction mixture containing $1 \times$ RT buffer $(72 \mathrm{mM}$
$\mathrm{KCl}, 3 \mathrm{mM} \mathrm{MgCl}$, $50 \mathrm{mM}$ Tris-Cl, $\mathrm{pH}$ 8.3), $10 \mathrm{mM}$ dithiothreitol (DTT), $1 \mathrm{mM}$ each of the four deoxyribonucleotide triphosphates (dNTP; Pharmacia LKB, Sweden), $20 \mathrm{U}$ of ribonuclease inhibitor (RNasin; Promega, Madison, WI), $200 \mathrm{U}$ of Superscript ${ }^{T M}$ reverse transcriptase (GIBCO BRL, Gaithersburg, MA) and primers. The primers were 5 $\mu \mathrm{M}$ random hexamers (Takara Inc., Tokyo) or $100 \mathrm{nM}$ oligo deoxythymidine (oligo $\mathrm{d}(\mathrm{T})_{12-18} ;$ Pharmacia). The reaction mixture was incubated at $23^{\circ} \mathrm{C}$ for $10 \mathrm{~min}$ (annealing), at $42^{\circ} \mathrm{C}$ for $1 \mathrm{hr}$ (elongation), at $95^{\circ} \mathrm{C}$ for $10 \mathrm{~min}$ (deactivation), then ice-chilled and divided into 2.5 $\mu \mathrm{l}$ of aliquots.

\section{PCR primers and conditions}

Eight oligonucleotides were synthesized (Sawaddy Technology, Inc., Tokyo) as PCR primers, designed to amplify the extracellular or cytoplasmic regions of $\mathrm{MPRL}-\mathrm{R}$ cDNAs and to generate $\mathrm{mPRL}-\mathrm{R}$ CDNA bearing a point mutation in the extracellular regions. The priming regions of CDNA synthesis using a truncated model of the two forms of $\mathrm{mPRL}-\mathrm{R}$ mRNA, PRL- $\mathrm{R}_{\mathrm{S}} 3$ and $\mathrm{PRL}-\mathrm{R}_{\mathrm{L}} 1$ (Clarke and Linzer, 1993) are shown in Fig. 1.

The sequences of primers were as follows: mPRLR-1; 5'-CTG AAGGGAGCCTCTGATCTATTGC-3', mPRLR-2; 5'-GGATTTGATA CTCATCTGCTAGAG-3', mPRLR-3K; 5'-CCTCGGTACCACTTTAT GTG-3', mPRLR-4; 5'-ATGCCATCTGCACTTGCTTACATG-3', mLTHR-1; 5'-GATTTCTCCTGGCCCCATCTACTCC-3', mLTHR-L1A; 5'-CATAGCTTCCATGACCAGAGTCAC-3', mLTHR-S3A; 5'-GCAT CCTTGAGACTAGATTATTGG-3', mLTHR-3K; 5'-ACATAAAGT GGTACCGAGGT-3' (Kpnl sites are underlined).

The cDNA sample was amplified by $P C R$ in a $40-\mu /$ reaction mixture containing $1 \times$ PCR buffer $\left(50 \mathrm{mM} \mathrm{KCl}, 1.5 \mathrm{mM} \mathrm{MgCl}_{2}, 10\right.$ $\mathrm{mM}$ Tris-Cl, $\mathrm{pH} 8.0$ ), $200 \mu \mathrm{M}$ each of dNTP, and primers as indicated below in each reaction. Sometimes, $148 \mathrm{kBq}$ of deoxycytidine $5^{\prime}$-[ $\alpha$ $\left.{ }^{32} \mathrm{P}\right]$ triphosphate $\left(\left[\alpha^{-32} \mathrm{P}\right] \mathrm{dCTP}\right)$ (Amersham, England) was added to

\section{Long form}
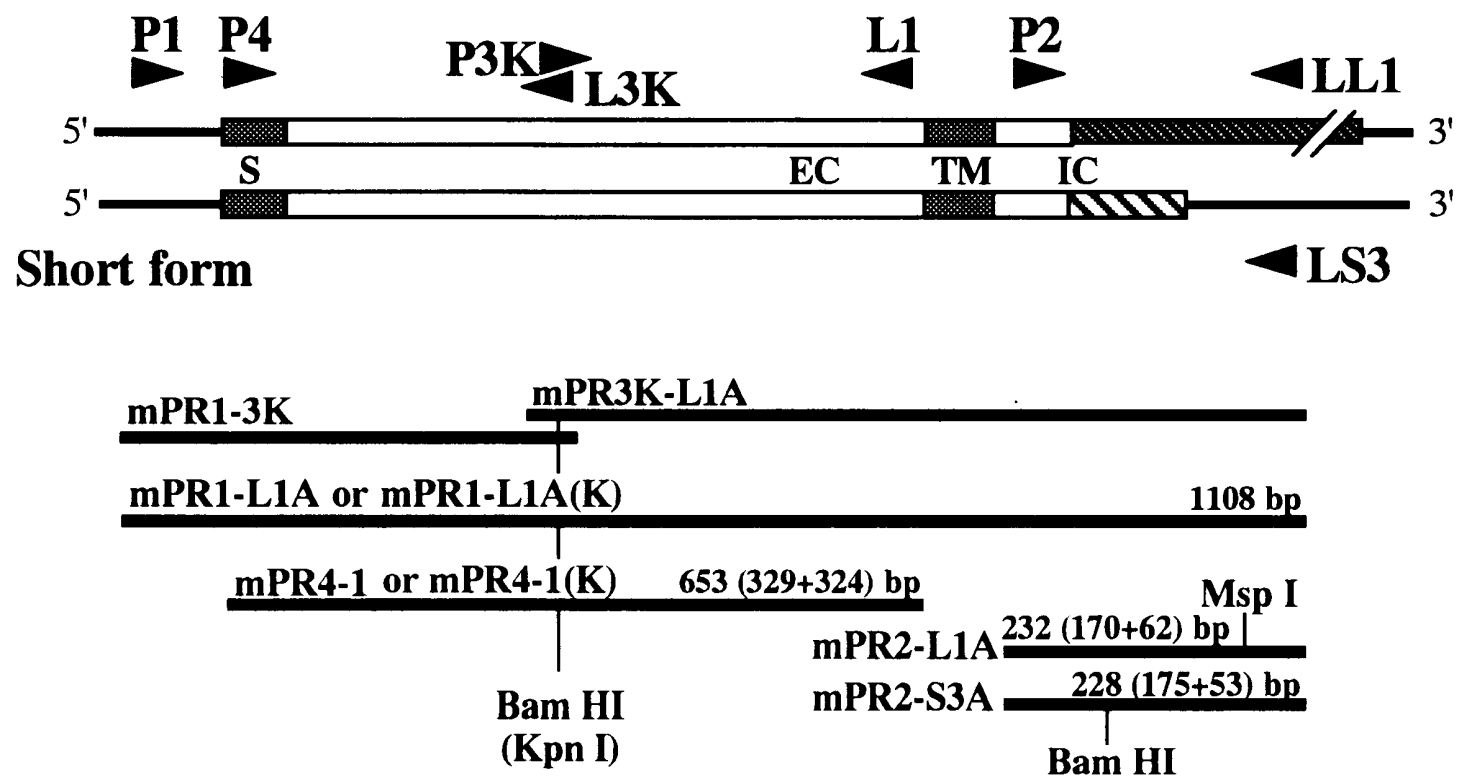

Fig. 1. A truncated model of two forms of PRL-R mRNAs (PRL- $R_{L} 1$ and PRL- $R_{S} 3$ ), regions of eight PCR primers, and DNA fragments amplified by PCR. The two forms have a common 5 flanking region and sequences corresponding to the signal peptide (S), extracellular domain (EC), transmembrane domain (TM) and part of the intracellular domain (IC). They differ in the $3^{\prime}$ region corresponding to IC (indicated with striped box) and in the $3^{\prime}$ flanking region. EC has a BamHI site at which double-strand CDNA is digested by the RE. IC of the long or short forms contains $\mathrm{Mspl}$ site or BamHI site, respectively. Arrowheads indicate regions of PCR primers. P1, mPRLR-1; P2, mPRLR-2; P3K, mPRLR3K; P4, mPRLR-4; L1, mLTHR-1; LL1, mLTHR-L1A; LS3, mLTHR-S3A; L3K, mLTHR-3K. Bold lines below indicate DNA fragments amplified by PCR, and the names and sizes are indicated above or on the left of them. Vertical thin lines indicate RE sites, and the sizes of cleaved fragments are indicated in parentheses. 
radioisotopically label the PCR products. The reaction mixture was overlaid with mineral oil (Sigma, St Louis, MO), and hot start PCR amplification proceeded using a thermal cycler (PTC-100; MJ Research, Inc., USA). After denaturation at $90^{\circ} \mathrm{C}$ for $5 \mathrm{~min}, 1 \mathrm{U}$ of Taq DNA Polymerase (Takara) was added to the reaction mixture, then 40 cycles of PCR amplification were performed. Each cycle consisted of denaturation at $94^{\circ} \mathrm{C}$ for $1 \mathrm{~min}$, annealing at $62^{\circ} \mathrm{C}$ for 1 min, and elongation at $72^{\circ} \mathrm{C}$ for $1 \mathrm{~min}$.

Preparation of competitor and standard DNA for CPCR and standard DNA for one-sided CPCR

Fragments of $\mathrm{MPRL}-\mathrm{R}$ cDNA were amplified from mouse liver cDNA by PCR using three sets of primers; $500 \mu \mathrm{M}$ each of mPRLR-1 and $m L T H R-L 1 A$, mPRLR-2 and mLTHR-L1A, and mPRLR-2 and $\mathrm{mLTHR}-\mathrm{S} 3 \mathrm{~A}$. The $P C R$ reaction mixture was resolved by electrophoresis on 1 or $2 \%$ agarose gel in $1 \times$ TAE buffer ( $40 \mathrm{mM}$ Trisacetate, $1 \mathrm{mM}$ EDTA, $\mathrm{pH} 8.0$ ). The gels were stained with ethidium bromide $(\mathrm{EtBr})$, and the PCR products were visualized with a UV transilluminator. Gel strips containing a single PCR product of the appropriate size $(1108,232$ or $228 \mathrm{bp}$, respectively) with a low background were excised. DNA was extracted from the gel using glass powder (Easytrap ${ }^{\top \mathrm{M}}$; Takara, Inc.) and subcloned into the pT7Blue(R)T vector (Novagen, Madison, WI) (mPR1-L1A(+)pT7B, mPR2L1A(+)pT7B or mPR2-S3A(+)pT7B, respectively). XL1-Blue (Stratagene, La Jolla, CA) was the host bacterium. The insert DNA was isolated from the plasmid by digestion with restriction enzymes (REs), EcoRI and Pstl, subcloned into pUC118/119 vectors, then sequenced as described (Akazome et al., 1994). We confirmed that they were derived from the target fragment of $\mathrm{mPRL}-\mathrm{R}$ cDNAs. All REs used here were obtained from Takara.

PCR was also used to generate a mutant of mPR1-1LA(+)pT7B bearing a Kpnl site (GGTACC) instead of a BamHI site (GGATCC) in the region corresponding to the extracellular domain of $\mathrm{mPRL}-\mathrm{R}$. MPR1-1LA(+)pT7B was linearized with HindIII, and PCR amplified using mPRLR-4 and $\mathrm{mLTHR}-3 \mathrm{~K}$ or using $\mathrm{mPRLR}-3 \mathrm{~K}$ and $\mathrm{mLTHR}$ $\mathrm{L} 1 \mathrm{~A}$ as primers. Each $\mathrm{PCR}$ product was subcloned into pT7Blue $(\mathrm{R})$ vector (mPR4-3K(+)pT7B and mPR3K-L1A(+)pT7B). Both plasmids were digested with $K p n l$, and the mPR4-3K(+)pT7B digest was dephosphorylated using calf intestine alkaline phosphatase (Takara) and ligated with the smaller fragment of MPR3K-L1A(+)pT7B digest to generate the mutant mPR1-1LA(+)pT7B bearing a Kpnl site (mPR1$1 \mathrm{LA}(\mathrm{K})(+) \mathrm{pT} 7 \mathrm{~B})$

Both plasmids, mPR1-1LA(+)pT7B and mPR1-1LA(K)(+)pT7B, were digested with Pstl and EcoRI, extracted with phenol-chloroform and precipitated with ethanol. They were then quantified by absorption at $260 \mathrm{~nm}(1 \mathrm{OD}$ unit was estimated at $50 \mu \mathrm{g} / \mathrm{ml})$, and used as the standard and the competitor DNA for CPCR, respectively.

Competitive PCR for the determination of rough amount of PRL-R cDNAs

PRL-R CDNA content was estimated by CPCR of CDNA samples (or standard DNA) with $10^{3}$ or $10^{7}$ molecules of competitor DNA using $500 \mu \mathrm{M}$ each of mPRLR-4 and mLTHR-1 as primers. The PCR product derived from the competitor bearing $K p n l$ site was distinguished from that from the tissue-derived native CDNA or the standard DNA bearing $B a m H I$ site by REs digestion. After digestion with either or both enzymes, the PCR products were resolved by electrophoresis on a $4 \%$ polyacrylamide gel in $1 \times$ TBE buffer ( $50 \mathrm{mM}$ Tris, $50 \mathrm{mM}$ boric acid, $1 \mathrm{mM}$ EDTA, pH 8.0) and stained with EtBr.

\section{One-sided CPCR for the determination of $S / L$ ratio}

PCR amplification of cDNAs proceeded in the presence of $[\alpha-$ ${ }^{32} \mathrm{P}$ ]dCTP using $100 \mu \mathrm{M}$ of mPRLR-2 and $500 \mu \mathrm{M}$ each of mLTHRL1A and mLTHR-S3A as primers. Smaller amount of the common primer (mPRLR-2) than the identical primers (mLTHR-L1A and $\mathrm{mLTHR}-\mathrm{S} 3 \mathrm{~A}$ ) reduced potential alteration of the $\mathrm{S} / \mathrm{L}$ ratio caused by exhaustion of the identical primers. The PCR product derived from the long form was distinguishable from that from the short form by having a restriction site for $\mathrm{BamHI}$ or $\mathrm{Mspl}$. The PCR mixture was digested with the enzymes, resolved by electrophoresis on $10 \%$ polyacrylamide gel in $1 \times$ TBE buffer, and stained with EtBr. The band corresponding to the larger fragment of digested PCR product was excised under UV light, transferred into a glass vial, then Cerenkov radiation was measured using a scintillation counter (LS6000IC; Beckman Instruments, Inc., Fullerton, CA). The PCR product without RE digestion was also resolved by electrophoresis, and a gel strip equivalent to the larger fragment of digested PCR product at the same position and size served as the background. The value of radiation intensity of gel corresponding to the larger fragment of $\mathrm{Mspl}$ or $\mathrm{BamHI}$ digest was divided by the number of deoxycytidine residues in the alignment ( 83 or 77 , respectively). The quotient was proportional to the number of long or short form mPRL-R CDNA molecules Sometimes, the gels were exposed to a Kodak X-OMAT film (Eastman Kodak, USA) after electrophoresis.

\section{Statistical analysis}

All results are expressed as the mean \pm S.E. Statistical significance of differences between means were assessed with Student's $t$-test. The number of samples is expressed as ' $n$ ' in parenthesis.

\section{RESULTS}

\section{One-sided CPCR with standard DNA samples}

To understand the relationship between the $S / L$ ratio of one-sided CPCR products and that of the cDNA before amplification, one-sided CPCR was performed with samples containing fixed amounts of standard plasmid DNAs, mPR2$\mathrm{L} 1 \mathrm{~A}(+) \mathrm{pT} 7 \mathrm{~B}$ and $\mathrm{mPR} 2-\mathrm{S} 3 \mathrm{~A}(+) \mathrm{pT} 7 \mathrm{~B}$ linearized by EcoRI digestion. After preparing standard samples containing $10^{3}$ or $10^{7}$ molecules in each tube and an $S / L$ ratio of $0.1,0.25,0.5$ 1,2 , or 4 , one-sided CPCR amplification of mPRL-R CDNA was performed and the $S / L$ ratio of the one-sided $C P C R$ products was measured (Fig. 2). The results showed that $S / L$ ratio was not altered by one-sided CPCR amplification. Hence one-sided CPCR was considered to be reliable for measuring the $S / L$ ratio, at least when it was between 0.1 and 4 and the amount of $\mathrm{mPRL}-\mathrm{R}$ cDNA molecules was between $10^{3}$ and $10^{7}$.

\section{Competitive $P C R$ for determination of rough amount of mouse PRL-R CDNA}

To reconfirm that the number of PRL-R cDNA molecules was between $10^{3}$ and $10^{7}$ in the CDNA sample, we developed CPCR with which to estimate the amount of MPRL-R CDNA. Competitive $P C R$ amplification proceeded with samples containing $10^{3}$ or $10^{7}$ molecules of standard DNA (mPR1L1A(+)pT7B) and competitor (mPR1-L1A(K)(+)pT7B) (10 $0^{2-4}$ or $10^{6-8}$ molecules, respectively) (Fig. 3A). The amount of PCR product cleaved by $B a m H I$ was more than by $K p n l$ when there was more standard than competitor, and vice versa. We then performed CPCR of each CDNA sample using $10^{3}$ or $10^{7}$ molecules of standard (cf. Fig. 3B). All cDNA samples used here contained more than $10^{3}$ and less than $10^{7}$ molecules of mPRL-R cDNA. 


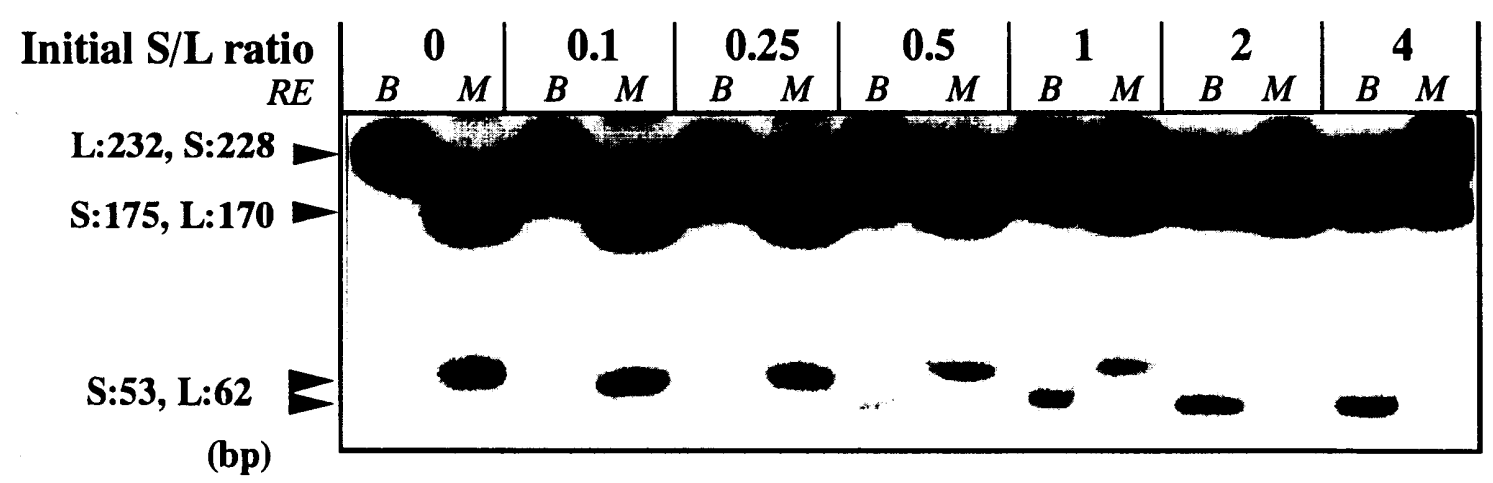

b

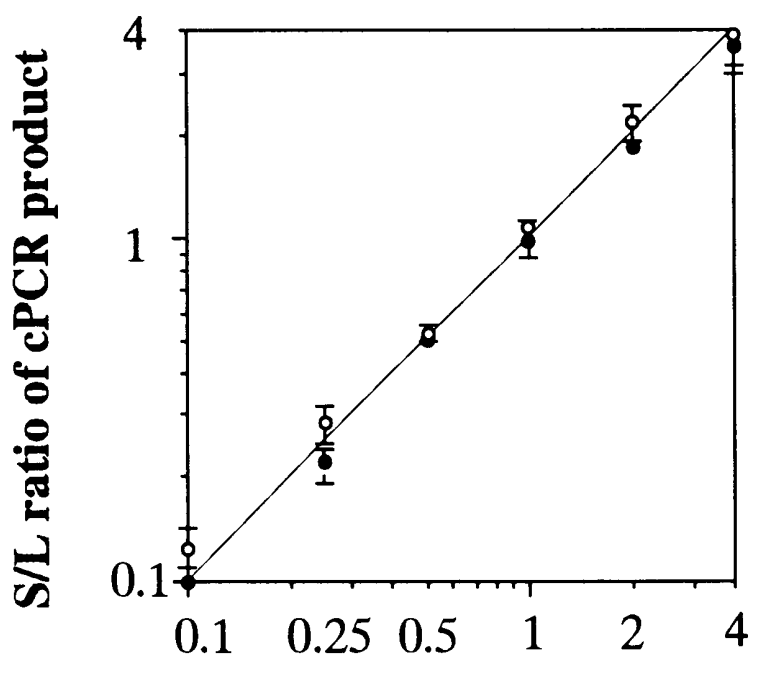

\section{Initial $\mathbf{S} / \mathbf{L}$ ratio}

\section{$S / L$ ratio in several tissues}

The $S / L$ ratio of CDNA in the liver, mammary gland, ovary, uterus, testis, small intestine, skeletal muscle and blood was determined by one-sided cPCR (Fig. 4). Oligo dT primer was used for the $R T$ reaction. The $S / L$ ratio was above 1 in the liver, but less than 1 in the mammary gland, ovary, uterus, testis, small intestine and skeletal muscle. No PCR product was observed in the blood. However, sufficient amount of onesided CPCR product was obtained from CDNA of the buffy coat which was separated by $1 \%$ dexistran from heparinized blood. We found that the long form was also dominant in the blood (data not shown). Thus, long form PRL-R mRNA is dominant in almost all mouse tissues except the liver.

\section{Effect of $P G$ on $S / L$ ratio in liver}

Hepatic cDNA samples were prepared in PG and control mice by the RT reaction using oligo dT primer or random primer. The $S / L$ ratios then determined by one-sided $C P C R$
Fig. 2. One-sided $C P C R$ products and its $S / L$ ratio obtained from amplification of standard DNA for long and short form $\mathrm{mPRL}-\mathrm{R}$ (mPR1-L1A/pT7B and mPR1-S3A/pT7B, respectively) combined in various initial proportions. a: After digestion with $\mathrm{BamHI}(\mathrm{B})$ or $\mathrm{Mspl}(\mathrm{M})$, amplification products were resolved on a $10 \%$ polyacrylamide gel and autoradiographed. The initial $S / L$ ratio and $R E$ are indicated on the top of the lanes. The amplification generated 232 and 228 bp products that corresponded to the long and short form mPRL-R, respectively. The product from the long form was digested by $M s p l$ into 170 and 62 bp fragments, and that from the short form was digested by BamHI into 175 and 53 bp fragments. b: Relationship between initial $S / L$ ratio and $S / L$ ratio determined by one-sided $C P C R$ after PCR amplification. The initial amount of standard DNA molecules was $10^{3}(O)$ or $10^{7}(O)$. Vertical bars indicate S.E. $(n=3-4)$.

(Fig. 5), were above 1 even when the random primer was used, suggesting that the short form was dominant in the liver. The $S / L$ ratio was consistently higher in $P G$ mice than in controls. Therefore, PG increased the amount of the short, rather than the long form of PRL-R mRNA in the mouse liver.

\section{DISCUSSION}

We established one-sided $\mathrm{CPCR}$ to determine the ratio of two types of mPRL-R cDNAs. The procedure was proved useful when the ratio was in the appropriate range. This protocol will be able to determine the ratio of two cDNAs derived from alternative splicing as long as the appropriate PCR primers are available. Those used here were designed to generate PCR products of a similar length and GC content, so as to amplify two cDNAs with the same efficiency.

A cPCR was also established to estimate the amount of mPRL-R cDNAs. A competitor DNA bearing a single mutation is hardly different in amplification efficiency from the target cDNA or other competitor DNAs bearing a small fragment insertion or heterologous competitor fragments. Thus, cPCR with competitor DNA bearing single mutation will provide a reliable means of quantifying a target DNA. However, the generation of target and competitor DNA heterodimers makes it difficult to quantify more precise changes in the amount of the target DNA. Control of the heterodimerization must be 


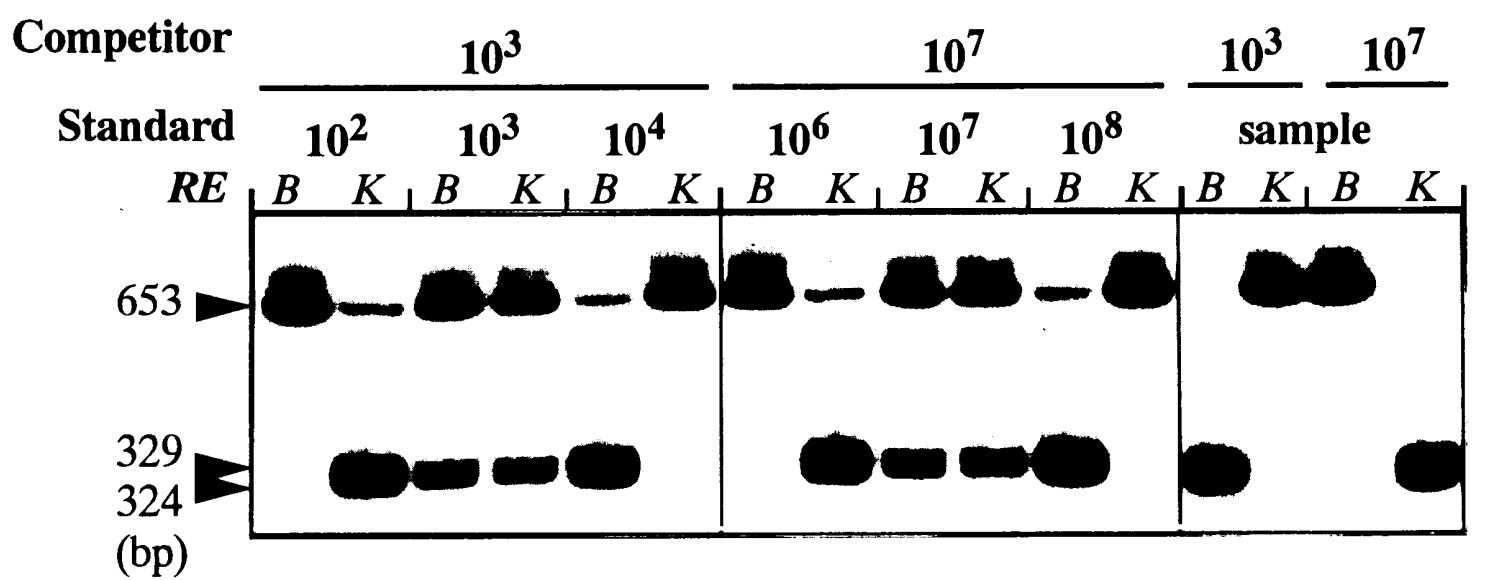

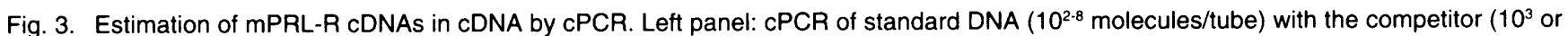
$10^{7}$ molecules/tube). Right panel: CPCR of a hepatic cDNA sample with competitor CDNA ( $10^{3}$ or $10^{7}$ molecules). PCR products were digested with BamHI (B) or Kpnl (K) and resolved on a 4\% polyacrylamide gel. The amplification generated a 653 bp product, some of which was cut into two fragments ( 329 and 324 bp) by the REs. The amount of PCR products digested by BamHI was more than that by Kpnl when the amount of standard DNA (or native MPRL-R CDNA in CDNA sample) was more than that of the competitor, and vice versa. The amount of native MPRL-R cDNA in the CDNA sample is more than $10^{3}$ and less than $10^{7}$ molecules.

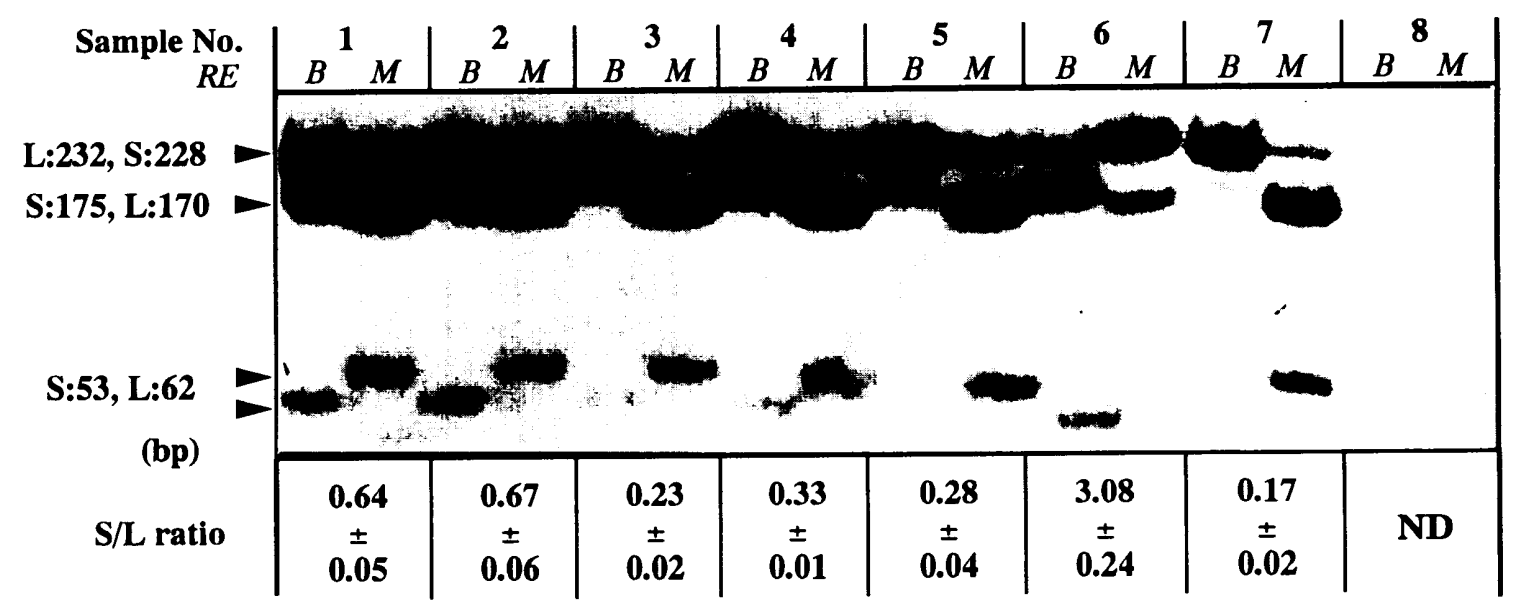

Fig. 4. One-sided $C P C R$ products and the $S / L$ ratio obtained from amplification of $C D N A$ from tissues. Amplification products of $c D N A$ from the small intestine, uterus, ovary, mammary gland, liver, skeletal muscle and blood of female mice and testis of males were digested by Mspl (M) or BamHI (B), resolved on $10 \%$ polyacrylamide gels and autoradiographed. Means $\pm S$.E. of their $S / L$ ratios are indicated on the bottom of the lane $(n=3-4)$. ND, not detected. The long form PRL-R was dominant only in the liver.

established.

The $S / L$ ratio of oligo dT-primed cDNA was considered to be larger than that of the original mRNA, since the efficiency of the $R T$ reaction of the target fragment may be higher in the short, than in the long form of PRL-R mRNA, because of the short distance from the poly $A$ site to the target sequence. In contrast, the $S / L$ ratio of random-primed CDNA sample is considered to be smaller than that of the original mRNA sample, because the efficiency of the RT reaction of target fragment may be lower in the short, than in the long form. An RT product with the full length of target fragment will not be obtained when RT reaction starts from inside the target fragment. In fact, the $S / L$ ratio of oligo dT-primed CDNA was larger than that of random-primed CDNA in the liver, and the $S / L$ ratio of mRNA sample should be between the two values.
The biological meaning of PRL-R heterogeneity is not fully understood. The PRL-induced expression of milk protein gene is mediated by the long, but not the short form receptor. However, there is no difference in the binding with the ligand or Jak 2 kinase between the two forms. In this study, hyperprolactinemia increased the $S / L$ ratio in the liver, suggesting that PRL affects the splicing or stability of PRL-R gene transcripts and up-regulates short form PRL-R expression. An increase in the $S / L$ ratio may down-regulate the function of the long form by removing the ligand or Jak 2 kinase. Moreover, a small increase in $S / L$ ratio will bring about a large reduction in the function of the long form, since homodimers of the long form receptor molecules only are functional in mediating the PRL-signal to the nuclei. Furthermore, not only the homodimer of the short form but 


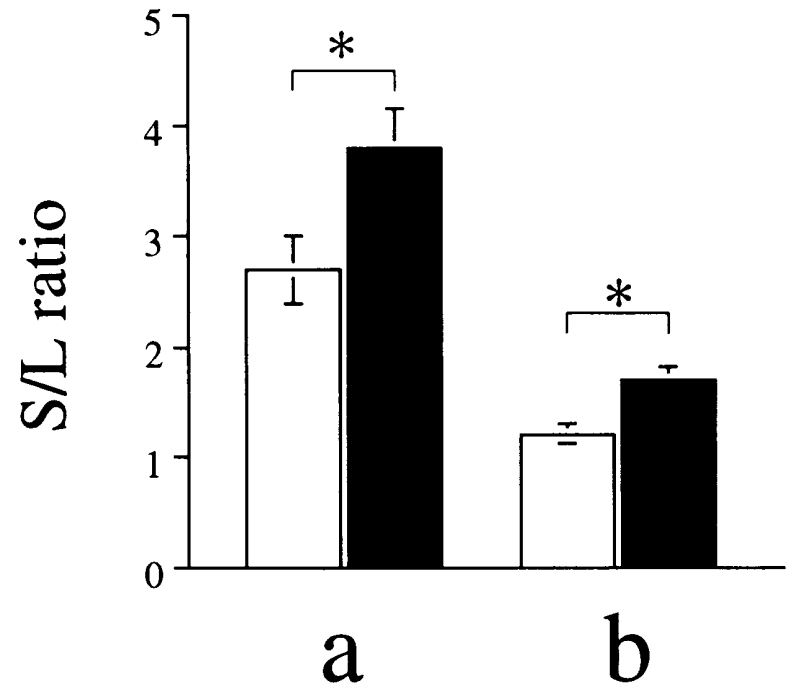

Fig. 5. Effect of $P G$ on the $S / L$ ratio in female mouse liver. Hepatic cDNA samples were prepared from female PG (black column) and control (clear column) mice by RT using oligo $\mathrm{dT}$ (a) or random hexamer (b) as the primer, and the $S / L$ ratios were measured by one-sided cPCR. Vertical bars indicate S.E. $(n=4)$. Statistical significance; ${ }^{*} p<0.05$.

also heterodimers of the long and short forms are nonfunctional. Thus, PRL is considered to modify tissue sensitivity to the hormone itself by altering PRL-R gene expression during post-transcription, although information concerning other short form PRL-Rs is needed to understand the precise effect of $P R L$ on PRL-R expression. Short form PRL-R in the liver may contribute to positive clearance of the ligand.

\section{ACKNOWLEDGMENTS}

We are grateful to Dr. S. Kawashima, Zenyaku Kogyo, Co., Ltd., Tokyo, and Dr. M. K. Park, Univ. of Tokyo, for valuable discussions. This research was supported by a Research Grant from JSPS Research Fellowships for Young Scientists and a Sasagawa Scientific Research Grant from the Japan Science Society to M. Matsuda, and by a Grant-in-Aid for Developmental Scientific Research from the Ministry of Education, Science, Sports and Culture, Japan to T. Mori.

\section{REFERENCES}

Akazome Y, Park MK, Mori T, Kawashima S (1994) Characterization of cDNA-encoding N-terminal region of the Quail lutropin receptor. Gen Comp Endocrinol 95: 222-231

Amit T, Barkey RJ, Gavish M, Youdim MB (1985) Induction of prolactin receptors by prolactin in the rat lung and liver: demonstration of separate receptor and antibody entities. Mol Cell Endocrinol 39: 21-29

Barash I, Cromlish W, Posner BI (1988) Prolactin (PRL) receptor induction in cultured rat hepatocytes: dual regulation by PRL and growth hormone. Endocrinology 122: 1151-1158

Boutin JM, Jolicoeur C, Okamura H, Gagnon J, Edery M, Shirota M, Banville DL, Dusanter-Fourt I, Djiane J, Kelly PA (1988) Cloning and expression of the rat prolactin receptor, a member of the growth hormone/prolactin receptor gene family. Cell 53: 69-77

Boutin JM, Edery M, Shirota M, Jolicoeur C, Lesueur L, Ali S, Gould D, Djiane L, Kelly PA (1989) Identification of a c DNA encoding a long form of prolactin receptor in human hepatoma and breast cancer cells. Mol Endocrinol 3: 1455-1461

Buch K, Vanex M, Groner B, Ball RK (1992) Multiple forms of prolactin receptor messenger ribonucleic acid are specifically expressed and regulated in murine tissues and the mammary cell line $\mathrm{HC} 11$. Endocrinology 130: 1108-1114

Becker-Andre M, Hahlbrock K(1989) Absolute mRNA quantification using the polymerase chain reaction (PCR). A novel approach by a PCR aided transcript titration assay (PATTY). Nuc Acid Res 17: $9437-9446$

Chelly J, Kaplan JC, Maire P, Gautron S, Kahn A (1988) Transcription of the dystrophin gene in human muscle and non-muscle tissue. Nature 333: 858-860

Chen X, Horseman ND (1994) Cloning, expression, and mutational analysis of the pigeon prolactin receptor. Endocrinology 135: 269 276

Chomczynski P, Sacchi N (1987) Single-step method of RNA isolation by acid guanidinium thiocyanate-phenol-chloroform extraction. Anal Biochem 162: 156-159

Clarke DL, Linzer DIH (1993) Changes in prolactin receptor expression during pregnancy in the mouse ovary. Endocrinology 133: 224232

Davis JA, Linzer DIH (1989) Expression of multiple forms of the prolactin receptor in mouse liver. Mol Endocrinol 3: 674-680

Dusanter-Fourt I, Djiane J, Kelly P (1988) Cloning and expression of the rat prolactin receptor, a member of the growth hormone/ prolactin receptor gene family. Cell 53: 69-77

Edery M, Jolicoeur C, Levi-Meyrueis C, Dusanter-Fourt I, Petridou B, Boutin JM, Lesueur L, Kelly PA, Djiane J (1989) Identification and sequence analysis of a second form of prolactin receptor by molecular cloning of complementary DNA from rabbit mammary gland. Proc Natl Acad Sci USA 86: 2112-2116

Gilliland G, Perrin S, Blanchard K, Bunn HF (1990) Analysis of cytokine mRNA and DNA: detection and quantitation by competitive polymerase chain reaction. Proc Natl Acad Sci USA 87: 27252729

Haldosen LA, Gustafsson JA (1990) Binding and cross-linking of iodinated rat prolactin to rat hepatic prolactin receptor. Mol Cell Endocrinol 71: 41-48

Hu Z-Z, Dufau ML (1991) Multiple and differential regulation of ovarian prolactin receptor messenger RNAs and their expression. Biochem Biophys Res Commun 27: 219-225

Kelly PA, Ali S, Rozakis M, Goujon L, Nagano M, Pellegrini I, Gould D, Djiane J, Edery M, Finidori J, Postel-Vinay MC (1992) The growth hormone/prolactin receptor family. Rec Prog Horm Res 48: 123-164

Lee MS, Chang KS, Cabanillas F, Freireich EJ, Trujillo JM, Stass SA (1987) Detection of minimal residual cells carrying the $t(14 ; 18)$ by DNA sequence amplification. Science 237: 175-178

Lesueur L, Edery M, Ali S, Paly J, Kelly PA, Djiane J (1991) Comparison of long and short forms of the prolactin receptor on prolactin-induced milk protein gene transcription. Proc Natl Acad Sci USA 88: 824-828

Matsuda M, Mori T, Park MK, Yanaihara N, Kawashima S (1994) Enhanced cell proliferation by hyperprolactinemia in both exocrine and endocrine pancreas in mice. Eur J Endocrinol 130: 187-194

Matsuda M, Mori T, Park MK, Kawashima S (1995) Modification of pancreatic digestive fuction by pituitary grafting in mice. Eur $\mathrm{J}$ Endocrinol 133: 221-226

Moore RC, Oka T (1993) Cloning and sequencing of the cDNA encoding the murine mammary gland long-form prolactin receptor. Gene 134: 263-265

Nagano M, Kelly PA (1994) Tissue distribution and regulation of rat prolactin receptor gene expression: Quantitative analysis by polymerase chain reaction. J Biol Chem 269: 13337-13345

O'Neal KD, Yu-Lee LY (1994) Differential signal transduction of the short, $\mathrm{Nb2}$, and long prolactin receptors: Activation of interferon 
regulatory factor- 1 and cell proliferation. J Biol Chem 269: 2607626082

Posner BI, Kelly PA, Friesen HG (1975) Prolactin receptors in rat liver: possible induction by prolactin. Science 187: 57-59

Sandra O, Sohm F, de Luze A, Prunet P, Edery M, Kelly P (1995) Expression cloning of a cDNA encoding a fish prolactin receptor. Proc Natl Acad Sci USA 92: 6037-6041

Scott P, Kessler MA, Schler LA (1992) Molecular cloning of the bovine prolactin receptor and distribution of prolactin and growth hormone receptor transcripts in fetal and utero-placental tissues. Mol Cell Endocrinol 89: 47-58

Shirota M, Banville DL, Ali S, Jolicoeur C, Boutin JM, Edery M, Djiane J, Kelly PA (1990) Expression of two forms of prolactin receptor in rat ovary and liver. Mol Endocrinol 4: 1136-1143

Savoie S, Patel BA, Posner BI (1985) Concentration of native prolactin and prolactin binding sites in hepatic subcellular fractions from hyperprolactinemic rats. Horm Metab Res 17: 131-135

Siebert PD, Larrick JW (1992) Competitive PCR. Nature 359: 557558

Sivitz WI, Lee EC (1991) Assessment of glucose transporter gene expression using the polymerase chain reaction. Endocrinology 128: $2387-2394$

Sugiyama T, Minoura H, Kawabe N, Tanaka M, Nakashima K (1994) Preferential expression of long form prolactin receptor mRNA in the rat brain during the oestrous cycle, pregnancy and lactation: hormones involved in its gene expression. J Endocrinol 141: 325333

Tanaka M, Maeda K, Okubo T, Nakashima K (1992) Double antenna structure of chicken prolactin receptor deduced from the cDNA sequence. Biochem Biophys Res Commun 188: 490-496

(Received December 27, 1995 / Accepted March 18, 1996) 